Acta vet. scand. 1967, 8, 123-135.

From the Department of Animal Diseases, University of Connecticut, Storrs, USA.

\title{
MYCOPLASMA: ISOLATION FROM PREPUCE AND SEMEN OF BULLS*)
}

\author{
By \\ H. Ern $\left.\phi^{\star \star}\right), W . N$. Plastridge and M. E. Tourtellotte
}

During the past decade many investigations have been carried out to determine the possibility of Mycoplasma being the causative agent in diseases of undetermined etiology. It has been shown that Mycoplasma will produce lesions in the female genital tract under experimental conditions, and with this in mind it seemed worthwhile to examine the occurrence of Mycoplasma in the genital tract of bulls using different methods and mediums to select an effective method for routine examination.

In 1947, British workers isolated mycoplasmas from the genital tracts of 18 of 64 cows with a history of infertility, and also from 6 bulls (7). These strains were divided into two groups, " $S$ " and "P" types, the former group was considered saprophytic and the latter group potentially pathogenic. This separation was mainly based on the more fastidious growth requirements of the " $P$ " types, especially the need for serum, but serologic differences were noted as well (4). The "P" strain was later named Mycoplasma bovigenitalium, while the " $S$ " type was found to be identical with Mycoplasma laidlawii (5). It is noteworthy that

*) Scientific contribution no. 266, Agricultural Experiment Station, University of Connecticut.

**) This investigation was supported, in part, by an International Fellowship from National Institutes of Health to the senior author, on leave of absence from the State Veterinary Serum Laboratory, Copenhagen, Denmark. 
within the "P" group, strains most difficult to grow were often those isolated from animals in herds, where the evidence was most suggestive of pathogenicity (6).

Danish workers also paid attention to the possibility of mycoplasmotic infertility. In 1949, a Mycoplasma was isolated from bull's semen, and there was a suspicion of infertility in cows served by this bull (17). Rasbech and Szabo (cit. 15) cultured the organisms from semen of 7 bulls. In 1955, Albertsen (1) isolated mycoplasmas from the semen of 33 of 35 bulls tested and demonstrated, in one case, that specimens collected through a permanent transurethral cannula did not contain organisms, whereas specimens collected in the usual way invariably did so. In a few cases, mycoplasmas were demonstrated in preputial washings. Albertsen classified all but one strain as M. bovigenitalium and neither fermentation reactions or complement fixation tests revealed any differences within the species. The possibility that strains isolated from these bulls could have any significance for the fertility level of the bulls was excluded, but the author stressed the fact that the possibility of pathogenicity, when transferred to the cows, could only be determined by transmission experiments.

In 1953, Terpstra (21) found mycoplasmas in the prepuce of bulls and in the vagina of cows. Bakos et al. (2) reported on the incidence of mycoplasmas in genital tracts of cattle in 1959, and speck (19) isolated mycoplasmas from semen and preputial washings from 15 of 93 bulls, and from 6 of 226 vaginal washings from cows from herds with a low conception rate.

In the United States, Barber \& Fabricant (3) first reported on the isolation of mycoplasmas from bull semen. These investigators succeeded in getting positive results from 14 of 36 bulls tested.

Until 1964 nothing had been proved in regard to the pathogenicity of mycoplasmas for the female genital tract, but that year, Hartman et al. (10) published results of infusion of the uterus of 8 heifers with 7.0 to $9.0 \mathrm{ml}$ of a broth culture of Mycoplasma agalactiae var. bovis, the isolate which had proved to be a natural pathogen for the udder (9). Varying degrees of endometritis, salpingitis, and salpingoperitonitis were produced. Recently, Hirth and co-workers $(11,12,13)$ added the same strain of Mycoplasma to bull semen prior to processing and freezing in liquid nitrogen, and demonstrated that the organism survived 
this treatment and was able to produce bilateral and chronic, suppurative salpingitis, and various degrees of endometritis in 4 of 12 heifers. The lesions were significant, since these 4 animals did not conceive even after as many as 5 inseminations. The Mycoplasma was recovered from cervicovaginal mucus for up to 8 months and also in pure culture from the lesions, which were most severe in the oviducts. In this connection it is interesting that British investigators have reported isolation of Mycoplasma from various parts of the female reproductive tract, and most frequently from the oviducts. They examined organs of cows from a herd with a significant incidence of infertility; 20 isolations were made from 33 oviducts. Gross lesions were seen occasionally. Histologic examinations were not made (14).

It appears from this review that after 20 years of consideration, we are safe in saying that some mycoplasmas do indeed cause infertility in cattle, mainly due to salpingitis. Recently, mycoplasmas have been isolated from an aborted fetus in Iowa (18). It will be interesting to see whether future investigations will prove that mycoplasmas are indeed a cause of abortion.

\section{MATERIAL AND METHODS}

1. Examinations of preputial samples of bulls (NESBA) ${ }^{\star}$ ) (a)

Mediums. One semisolid, primary medium (Albertsen, modified) was used with a base of heart infusion broth (Difco), glucose (1\%), yeast extract $(0.5 \%$, Difco), agar $0.1 \%$. After autoclaving, horse serum $(10 \%)$, fresh yeast extract $(10 \%)$, penicillin $(100$ i.u. $/ \mathrm{ml})$, and thallium acetate $(1: 2000)$ were added. The fresh yeast extract was that of Taylor-Robinson et al. (20) at $\mathrm{pH}$ 7.4.

One plating medium was used, with a base of heart infusion broth (Difco), yeast extract $(0.5 \%$ Difco), agar $2 \%$, supplemented with PPLO serum fraction $(1 \%)$, horse blood $(5 \%)$, fresh yeast extract (10\%), thallium acetate $(1: 2000)$, and penicillin $(100 \mathrm{i} . \mathrm{u} . / \mathrm{ml})$.

Technique. The primary medium was dispensed in $10 \mathrm{ml}$ amounts in $3 / 4 \times 6$ inch screw-cap vials and mailed to NESBA. The NESBA personnel $^{\star \star}$ ) performed the removal of preputial material by introducing the medium into the prepuce by means of a sterile plastic tube $3 / 8$ inch outside diameter and 19 inches in length, after clipping the hair around the orifice and disinfecting the skin with a quaterinary ammonium compound. The sheath was massaged, after closing the orifice by hand, and the liquid retrieved with a suction bulb placed

*) New England Selective Breeding Association.

**) The authors wish to thank the NESBA personnel for their help and interest in this work. 
on the end of the plastic tube, and transferred to sterile tubes which were mailed back to the laboratory.

After 3, 5, and 7 days of incubation, $0.1 \mathrm{ml}$ of the primary medium culture was streaked on plating medium and incubated up to 10 days in air plus $10 \% \mathrm{CO}_{2}$.

Suspect colonies were stained after the method of Dienes, as described by Klieneberger-Nobel (16).

\section{Examination of preputial samples of bulls (NESBA) (b)}

Mediums. The same primary, semisolid medium as in experiment 1 was used. Also a secondary, liquid medium was used, consisting of Bacto brain heart infusion, supplemented after autoclaving with PPLO serum fraction $(1 \%)$, a solution of nucleosides $(0.5 \%)$, fresh yeast extract $(10 \%)$ (Taylor-Robinson et al.), penicillin 100 i.u. $/ \mathrm{ml}$ and thallium acetate $(1: 2000)$.

Three plating mediums were used. One was that of experiment 1 , the second was Bacto PPLO agar, supplemented with solution of nucleosides $(0.005 \%)$, PPLO serum fraction (1\%), horse blood $5 \%$, penicillin 100 i.u. $/ \mathrm{ml}$, and thallium acetate $(1: 2000)(8)$. The third medium was the same as the second to which $10 \%$ fresh yeast extract was added.

Technique. The preputial sample was obtained as in experiment 1. After 4 days' incubation of the primary medium cultures, $0.5 \mathrm{ml}$ was inoculated into the liquid medium, and the three solid mediums were inoculated with $0.05 \mathrm{ml}$ and incubated in air. After 4 days' incubation the broth was streaked on the solid mediums, incubated in air, and air with $10 \% \mathrm{CO}_{2}$.

\section{Examination of preputial samples of bulls (NESBA) (c)}

Mediums. Primary, semisolid medium and secondary, liquid medium were the same as in experiment 2.

Two plating mediums were used, namely Bacto PPLO horse blood agar with nucleosides, PPLO serum fraction, and fresh yeast extract; and heart infusion agar with fresh yeast extract and PPLO serum fraction. Both mediums contained penicillin and thallium acetate.

Technique. The preputial sample was obtained as in experiment 1 . After 4 days' incubation of primary medium cultures, $0.5 \mathrm{ml}$ was inoculated into secondary liquid medium and incubated for 10 days. The secondary medium was plated after 5 and 10 days; and also a subculture $(0.5 \mathrm{ml})$ into the same broth, was made after 5 days. This culture was plated after 5 days' incubation.

All plates were incubated in air and examined regularly after 3 to 4 days of incubation until day 10 .

\section{Examination of semen samples of bulls known to harbor Myco- plasma in the prepuce}

Mediums. The mediums were as in experiment 3, except only one plating medium was used, namely Bacto PPLO horse blood agar with nucleosides, PPLO serum fraction, and fresh yeast extract. 
Technique. Immediately after the drawing, $0.1 \mathrm{ml}$ of semen was inoculated into the primary medium, and the same procedure as used in experiment 3 was followed.

5. Examination of semen samples of bulls not known to harbor Mycoplasma in the prepuce

Mediums and technique were as in experiment 4, except that the semen was sent to the laboratory in cooled vials; consequently, the inoculation of primary medium was done at the laboratory.

\section{RESULTS}

1. Examination of preputial samples (a)

Preputial samples from 14 bulls were examined using a modification of the mediums and technique of Albertsen (1).

Two isolations were made by streaking, after 3 days of incubation of the primary culture in the semisolid medium; streaking after 5 days' incubation yielded one strain only; and after 7 days' incubation all cultures were negative.

The results indicate that subcultures should be made, rather than repeated streaking from the same culture.

\section{Examination of preputial samples (b)}

Preputial samples from 16 bulls were examined. Three mediums were compared: (1) Heart infusion horse blood agar with PPLO serum fraction and fresh yeast extract; (2) PPLO horse blood agar with nucleosides, PPLO serum fraction and fresh yeast extract; (3) PPLO horse blood agar with PPLO serum fraction and nucleosides. The latter medium (no yeast extract) gave only 2 isolations, while the others containing yeast extract gave 6 isolations.

Streaking from the primary medium gave a maximum of 2 isolations, while 6 were obtained by streaking from broth subcultures.

Incubation in air and air with $10 \% \mathrm{CO}_{2}$ have the same number of isolations, but aerobic incubation in some cases gave better results in terms of grade of hemolysis and number of colonies (Table 1).

\section{Examination of preputial samples (c)}

Preputial samples from 15 bulls and 1 steer (J.M.) were examined.

When heart infusion horse blood agar with PPLO serum fraction and fresh yeast extract was used as the plating medium, 
Ta ble 1. Examination of preputial samples of bulls (b).

\begin{tabular}{|c|c|c|c|c|c|c|c|c|c|}
\hline \multirow{4}{*}{$\begin{array}{l}\text { Name of } \\
\text { bull }\end{array}$} & \multirow{2}{*}{\multicolumn{3}{|c|}{$\begin{array}{l}\text { Heart infusion horse blood } \\
\text { agar with PPLO serum fraction } \\
\text { and fresh yeast extract }\end{array}$}} & \multicolumn{6}{|c|}{ PPLO horse blood agar with nucleosides, PPLO serum fraction } \\
\hline & & & & \multirow{3}{*}{$\begin{array}{l}\text { Plated } \\
\text { from } \\
\text { primary } \\
\text { medium } \\
\text { Air }\end{array}$} & \multirow{3}{*}{\multicolumn{2}{|c|}{$\begin{array}{l}\begin{array}{c}\text { Plated from } \\
\text { secondary medium }\end{array} \\
\text { Air } \quad 10 \% \stackrel{\mathrm{Air}}{+} \mathrm{CO}_{2}\end{array}$}} & \multicolumn{3}{|c|}{+ fresh yeast extract } \\
\hline & \multirow{2}{*}{$\begin{array}{l}\text { Plated } \\
\text { from } \\
\text { primary } \\
\text { medium } \\
\text { Air }\end{array}$} & \multicolumn{2}{|c|}{$\begin{array}{l}\text { Plated from } \\
\text { secondary medium }\end{array}$} & & & & \multirow{2}{*}{$\begin{array}{c}\text { Plated } \\
\text { from } \\
\text { primary } \\
\text { medium } \\
\text { Air }\end{array}$} & \multicolumn{2}{|c|}{$\begin{array}{l}\text { Plated from } \\
\text { secondary medium }\end{array}$} \\
\hline & & Air & $\underset{10 \% \mathrm{CO}_{2}}{\mathrm{Air}}+$ & & & & & Air & $\underset{10 \% \mathrm{CO}_{2}}{\mathrm{Air}}$ \\
\hline Eric & + & ++ & + & 0 & 0 & 0 & + & ++ & + \\
\hline Emory & + & ++ & + & 0 & 0 & 0 & + & ++ & + \\
\hline Acme & 0 & ++ & ++ & 0 & ++ & ++ & + & ++ & ++ \\
\hline Admiral & 0 & ++ & + & 0 & 0 & 0 & 0 & ++ & + \\
\hline Hominy & 0 & ++ & ++ & 0 & 0 & 0 & 0 & ++ & ++ \\
\hline Creator & 0 & + & + & 0 & + & + & 0 & + & + \\
\hline Laddie & B & B & B & B & B & B & B & B & B \\
\hline Ginger & B & B & B & B & B & B & B & B & B \\
\hline Phareka & B & B & B & B & B & B & B & B & B \\
\hline Fond & 0 & B & B & 0 & B & B & 0 & B & B \\
\hline Piebe & 0 & 0 & 0 & 0 & 0 & 0 & 0 & 0 & 0 \\
\hline Olan & 0 & 0 & 0 & 0 & 0 & 0 & 0 & 0 & 0 \\
\hline Lucifer & 0 & 0 & 0 & 0 & 0 & 0 & 0 & 0 & 0 \\
\hline Car & 0 & 0 & 0 & 0 & 0 & 0 & 0 & 0 & 0 \\
\hline Mo Mar & 0 & 0 & 0 & 0 & 0 & 0 & 0 & 0 & 0 \\
\hline Shaws & 0 & 0 & 0 & 0 & 0 & 0 & 0 & 0 & 0 \\
\hline Positive (6) & 2 & 6 & 6 & 0 & 2 & 2 & 3 & 6 & 6 \\
\hline
\end{tabular}

Growth: $+=1-100$ colonies of Mycoplasma; $++=100-500$ colonies of Mycoplasma; $B=$ Bacterial growth; $0=$ No colonies.

Note: All mediums were supplemented with penicillin (100 i.u. $/ \mathrm{ml})$ and thallium acetate $(1: 2000)$.

3 isolations were made (Table 2 a); 5 isolations were made when the solid medium was Bacto PPLO agar with horse blood (5\%), PPLO serum fraction $(1 \%)$, fresh yeast extract $(10 \%)$ and $0.005 \%$ of nucleosides (Table $2 \mathrm{~b}$ ).

Primary cultures in semisolid medium were not plated, but when a liquid subculture was plated after 5 days' incubation, 4 isolations were made; 2 of these were not isolated when the subcultures were streaked again after 10 days' incubation, on the other hand 1 new isolation was made, giving a total of 5 isolations.

When liquid subcultures of second order were plated after 5 days' incubation, only 3 isolations were made (Table $2 \mathrm{a}$ and $\mathbf{b}$ ). 
T a b l e 2 a. Examination of preputial samples of bulls (c).

Growth on heart infusion horse blood agar with PPLO serum fraction and fresh yeast extract

\begin{tabular}{lccc}
\hline $\begin{array}{l}\text { Name of } \\
\text { bull }\end{array}$ & $\begin{array}{c}\text { Plated from 1st } \\
\text { subinoculation } \\
\text { after 5 days } \\
\text { of incubation }\end{array}$ & $\begin{array}{c}\text { Plated from 1st } \\
\text { subinoculation } \\
\text { after 10 days } \\
\text { of incubation }\end{array}$ & $\begin{array}{c}\text { Plated from 2nd } \\
\text { subinoculation } \\
\text { after 5 days } \\
\text { of incubation }\end{array}$ \\
\hline Diadem & ++ & ++ & ++ \\
Lee & ++ & 0 & ++ \\
Ace & + & 0 & + \\
Maxim & 0 & 0 & 0 \\
J. M. & 0 & 0 & 0 \\
Sir & B & B & 0 \\
Laird & B & 0 & 0 \\
Bruce & B & B & 0 \\
Ton & B & 0 & 0 \\
Eil & B & B & 0 \\
Maple & B & B & 0 \\
Ben Hur & B & B & 0 \\
Sibu & 0 & 0 & 0 \\
Ray & 0 & 0 & 0 \\
Ruler & 0 & 0 & 0 \\
Kie & 0 & 0 & 0 \\
\hline Positive $(3)$ & 3 & 1 & 3 \\
\hline
\end{tabular}

4. Examination of semen samples from bulls known to harbor Mycoplasma in the prepuce

Twelve semen samples from bulls, which the three previous experiments had demonstrated to be infected with mycoplasmas in the prepuce, were examined. Two isolations were made by streaking from liquid subcultures of both first and second order on PPLO horse blood agar with nucleosides, PPLO serum fraction, and fresh yeast extract.

5. Examination of semen samples from bulls from which Mycoplasma had not been isolated

Semen samples from 33 bulls, which had not yielded mycoplasmas when preputial material was tested, were examined.

One isolation was made by streaking from liquid subcultures of both first and second order on PPLO horse blood agar with nucleosides, PPLO serum fraction, and fresh yeast extract. 
T a b l e 2 b. Examination of preputial samples of bulls (c).

\begin{tabular}{lccc}
\hline \multicolumn{4}{c}{$\begin{array}{c}\text { Growth on Bacto PPLO horse blood agar } \\
\text { with nucleosides, PPLO serum fraction and fresh yeast extract }\end{array}$} \\
$\begin{array}{lccc}\text { Name of } \\
\text { bull }\end{array}$ & $\begin{array}{c}\text { Plated from 1st } \\
\text { subinoculation } \\
\text { after 5 days } \\
\text { of incubation }\end{array}$ & $\begin{array}{c}\text { Plated from 1st } \\
\text { subinoculation } \\
\text { after 10 days } \\
\text { of incubation }\end{array}$ & $\begin{array}{c}\text { Plated from 2nd } \\
\text { subinoculation } \\
\text { after 5 days } \\
\text { of incubation }\end{array}$ \\
\hline Diadem & ++ & ++ & ++ \\
Lee & ++ & 0 & +++ \\
Ace & + & 0 & + \\
Maxim & + & + & 0 \\
J. M. & 0 & ++ & 0 \\
Sir & B & B & 0 \\
Laird & B & 0 & 0 \\
Bruce & B & B & 0 \\
Ton & B & 0 & 0 \\
Eil & B & B & 0 \\
Maple & B & B & 0 \\
Ben Hur & B & B & 0 \\
Sibu & 0 & 0 & 0 \\
Ray & 0 & 0 & 0 \\
Ruler & 0 & 0 & 0 \\
Kie & 0 & 0 & 0 \\
\hline Positive $(5)$ & 4 & 3 & 3 \\
\hline
\end{tabular}

Growth: $+=1-100$ colonies of Mycoplasma; $++=100-500$ colonies of Mycoplasma; $+++=$ More than 500 colonies of Mycoplasma; $\mathrm{B}=$ Bacterial colonies; $0=$ No colonies.

Incubation: Aerobic.

Note: All mediums were supplemented with penicillin (100 i.u. $/ \mathrm{ml})$ and thallium acetate $(1: 2000)$.

\section{DISCUSSION AND CONCLUSIONS}

Prior to the examinations reported herein, 10 semen samples were cultured using the mediums and procedures of Albertsen (1) and Barber \& Fabricant (3) together with enriched Bacto PPLO agar. As no positive results were obtained, attention was focused on examination of preputial material, since contamination of semen probably takes place in the prepuce (Albertsen), and it is reasonable to assume that a semen sample may be free of mycoplasmas, even if the prepuce is infected, if the sample is drawn using good techniques. 
For these reasons it was decided to examine preputial material in three series, and later to examine semen samples of all bulls belonging to NESBA, modifying methods and mediums according to the results obtained.

In the examination of the first series of samples, modifications of the mediums of Albertsen were used because Albertsen had obtained the highest percentage of isolations. The medium of Barber \& Fabricant (pig stomach extract) was omitted because the procedure of making it is time consuming, and because of unavoidable differences in the composition of different lots of the medium.

In the primary semisolid medium, fresh beef heart infusion was replaced by heart infusion broth (Difco); this was also the case with the plating medium which was further modified by the addition of horse blood (5\%) and replacement of horse serum $20 \%$ with PPLO serum fraction (1\%). These modifications were justified by the results of preceding nutritional studies (8).

The first series of samples of preputial material yielded 2 strains of Mycoplasma and the experiment further indicated that subcultures of the primary medium should be done, rather than repeated platings. This was, therefore, done in the examination of the second series of samples; Bacto brain heart infusion broth with PPLO serum fraction ( $1 \%)$, nucleosides $(0.005 \%)$, and fresh yeast extract $(10 \%)$ was used as the secondary medium from which plating was done on three different mediums, namely that of Albertsen (modified), Bacto PPLO horse blood agar with PPLO serum fraction and nucleosides, and the latter supplemented with $10 \%$ fresh yeast extract. Although the nutritional studies of laboratory strains had not demonstrated a need for yeast extract, inclusion of yeast extract in mediums for the isolation of field strains appeared desirable. The method of Taylor-Robinson et al. (20) was used to prepare the yeast extract, because this group also used Bacto PPLO agar as a base for their mediums. A liquid subculture medium was preferred to a semisolid one because the latter, when plated, leaves pieces of agar which, in some cases, appear similar to small Mycoplasma colonies; it must be mentioned here that the staining method of Dienes is a great help in deciding whether a suspect formation is, in fact, a colony of mycoplasmas.

The examination of the second series of samples yielded 6 
strains of mycoplasmas, of which 4 appeared only after plating from secondary medium. In accordance with nutritional studies (8), there was not any great difference in whether incubation was done in air or in air plus $10 \% \mathrm{CO}_{2}$, but in a few cases growth was best under aerobic conditions. Only 2 strains were isolated on mediums without yeast extract, while mediums with this enrichment yielded 6 isolates.

In the third series of preputial samples it was demonstrated that a plating from a subculture of segond order did not yield more strains, on the contrary, 2 strains were lost by this procedure. A second streaking from the first subculture after 10 days' incubation gave one new isolate but 2 strains were lost.

T a b l e 3. Summary of cultural tests for Mycoplasma in preputial samples and semen from 45 bulls.

\begin{tabular}{ccl}
\hline $\begin{array}{c}\text { Number } \\
\text { of bulls }\end{array}$ & $\begin{array}{c}\text { Preputial } \\
\text { samples }\end{array}$ & Semen \\
\hline 2 & positive & positive \\
10 & positive & negative \\
1 & negative & positive \\
32 & negative & negative \\
\hline
\end{tabular}

Examination of semen samples, using the technique designed after experiences with the culturing of preputial samples, demonstrated that it is necessary to culture both preputial material and semen to determine whether a bull harbors mycoplasmas in the genital tract (Table 3). Most isolates can be made from preputial material, but a heavy bacterial contamination will probably, in some cases, mask mycoplasmas and, in these cases, there is a chance of making an isolation from a semen sample, although this is dependent upon the number of mycoplasmas present and the skill with which the sample is drawn. As demonstrated in Tables 1 and 2 , bacterial growth was in fact present in many cases, therefore, it might be necessary to examine preputial material after filtration in order to obtain the most reliable results.

On the basis of nutritional and field experiments it was concluded that good results were obtained by primary culturing in a semisolid medium, secondary culturing in a liquid medium, and plating liquid subculture, after 5 and 10 days of incubation, 
on a medium consisting of Bacto PPLO agar with PPLO serum fraction $(1 \%)$, horse blood $(5 \%)$, nucleosides $(0.005 \%)$ and fresh yeast extract $(10 \%)$. All mediums contained penicillin (100 i.u./ml) and thallium acetate $(1: 2000)$.

\section{REFERENCES}

1. Albertsen, B. E.: Pleuropneumonia-like organisms in the semen of Danish artificial insemination bulls. Nord. Vet.-Med. 1955, 7, 169-200.

2. Bakos, K., A. Bane \& E. Thal: Incidence of PPLO in the genital tract of cattle. Proc. 16th Int. Vet. Congr., Madrid 1959, 2, $543-545$.

3. Barber, T. L. \& J. Fabricant: Primary isolation of Mycoplasma organisms (PPLO) from mammalian sources. J. Bact. 1962, $83,1268-1273$.

4. Edward, D. G. ff.: An investigation of pleuropneumonia-like organisms from the bovine genital tract. J. gen. Microbiol. $1950,4,4-15$.

5. Edward, D. G. ff.: The pleuropneumonia group of organisms: A review together with some new observations. J. gen. Microbiol. 1954, 10, 27-64.

6. Edward, K. G. ff. \& W. A. Fitzgerald: A growth factor needed to isolate organisms of the pleuropneumonia group from the genital tract of cattle. Vet. Rec. 1952, 64, 395-396.

7. Edward, D. G. ff., J. L. Hancock \& S. L. Hignett: Isolation of pleuropneumonia-like organisms from the bovine genital tract. Vet. Rec. 1947, 59, 329-330.

8. Ernф, H., W. N. Plastridge \& M. E. Tourtellotte: Mycoplasma: Nutritional studies of laboratory strains. Acta vet. scand. 1967, 8, 111-122.

9. Hale, H. H., C. F. Helmboldt, W. N. Plastridge \& E. F. Stula: Bovine mastitis caused by a Mycoplasma species. Cornell Vet. 1962, $52,582-591$.

10. Hartman, H. A., M. E. Tourtellotte, S. W. Nielsen \& W. N. Plastridge: Experimental bovine uterine mycoplasmosis. Res. vet. Sci. $1964,5,303-310$.

11. Hirth, R. S., W. N. Plastridge \& M. E. Tourtellotte: Survival of a Mycoplasma in frozen bull semen. Amer. J. vet. Res. In press.

12. Hirth, R. S., S. W. Nielsen \& W. N. Plastridge: Bovine salpingooophoritis produced with semen containing a Mycoplasma. In preparation.

13. Hirth, R. S., W. N. Plastridge, M. E. Tourtellotte \& S. W. Nielsen: Genital mycoplasmosis in cattle and man. J. Amer. vet. med. Ass. 1966, 148, 277-282. 
14. Hoare, M. \& D. A. Haig: Isolation of Mycoplasma sp. from the oviducts of dairy cows. Vet. Res. 1964, 76, 956-957.

15. Karlsh $\phi, K . \&$ N. O. Rasbech: Unders $\varnothing$ gelser over spermielevedygtighed og bakterievækst i tyresæd fortyndet med forskellige fortyndingsvæsker. Nord. Vet.-Med. 1949, 1, 643-668.

16. Klieneberger-Nobel, E.: Pleuropneumonia-like Organisms (PPLO) : Mycoplasmataceae. Academic Press, Inc., New York 1962.

17. Nielsen, F.: Sterility in cattle, especially as a result of uterine infection. Proc. 14th Int. Vet. Congr., London 1949, 3, 105113.

18. O'Berry, P. A., F. H. Bryner \& A. Frank: Isolation of Mycoplasma from an aborted fetus and vaginal mucus. J. Amer. vet. med. Ass. 1965, 147, 1666.

19. Speck, J.: PPLO from the genital system of cattle. Mh. Tierheilk. 1962, 14, 244-256. (Original not seen: Vet. Bull. 1963, 33, 130, no. 788).

20. Taylor-Robinson, D., N. L. Somerson, H. C. Turner \& R. M. Chanock: Serological relationships among human Mycoplasma as shown by complement-fixation and gel diffusion. J. Bact. $1963,85,1261-1273$.

21. Terpstra, J. I.: A case of "Enzootic Sterility" (Vibrio fetus; pleuropneumonia-like organisms). Proc. 15th Int. Vet. Congr., Stockholm 1953, 2, 811-816.

\section{SUMMARY}

Mycoplasmas were isolated from the prepuce of 12 of 45 bulls and the semen of 2 of the 12 preputial-positive animals, and also from the semen of 1 of the 33 bulls which had not yielded mycoplasmas in the preputial sample. It appears, therefore, necessary to examine both preputial material and semen to detect potential shedders of Mycoplasma. Addition of fresh yeast extract to a solid medium of Bacto PPLO agar + Bacto PPLO serum fraction (1\%) + horse blood (5\%), and $0.005 \%$ of 8 nucleosides (adenosine, cytidine, deoxyadenosine, deoxycytidine, deoxyguanosine, guanosine, thymidine, and uridine) enhanced the number of isolations considerably. Aerobic incubation was preferable to incubation with air plus $10 \% \mathrm{CO}_{2}$.

\section{ZUSAMMENFASSUNG}

Mykoplasma: Isolation von Präputium und Sperma beim Bulle.

Mykoplasmen wurden vom Präputium von 12 der 45 untersuchten Bullen gezüchtet. In Spermaproben von 2 von den 12 präputium-positiven Bullen sowie von 1 der 33 Bullen, die bei der Züchtung aus der Vorhaut negativ waren, wurden ebenfalls Mykoplasmen nachgewiesen. Es scheint daher notwendig zu sein sowohl Vorhautproben wie Sper- 
ma zu untersuchen um potentielle mykoplasmaausscheidende Tiere zu finden. Durch den Zusatz eines frischen Hefeextraktes zu einem festen Medium bestehend aus Bacto PPLO Agar mit Bacto PPLO Serum Fraktion $(1 \%)$, Pferdeblut $(5 \%)$ und $0,005 \%$ von 8 Nukleosiden (Adenosin, Cytidin, Deoxyadenosin, Deoxycytidin, Deoxyguanosin, Guanosin, Thymidin und Uridin) wurde die Anzahl der Isolationen wesentlich erhöht. Aerobe Züchtung war einer Züchtung in atmosphärischer Luft mit $10 \% \mathrm{CO}_{2}$ vorzuziehen.

\section{SAMMENDRAG}

Mykoplasma: Isolation fra præputium og sæd hos tyr.

Mykoplasmer dyrkedes fra præputium af 12 af 45 unders $\emptyset$ gte tyre, fra sædprøver af 2 af de 12 præputium-positive dyr og fra sæden af 1 af de 33 tyre, som var negative ved dyrkning fra forhuden. Det synes derfor nødvendigt at unders $\emptyset$ ge både forhudspr $\varnothing$ ver og sæd for at finde potentielle udskillere af mykoplasmer. Ved at tilsætte frisk gærekstrakt til et fast medium bestående af Bacto PPLO agar med Bacto PPLO serum fraktion (1\%), hesteblod $(5 \%)$ og $0,005 \%$ af 8 nukleosider (adenosin, cytidin, deoxyadenosin, deoxycytidin, deoxyguanosin, guanosin, thymidin og uridin) forøgedes antallet af isolationer væsentligt. Aerob dyrkning var at foretrække for dyrkning $i$ atmosfærisk luft med $10 \% \mathrm{CO}_{2}$. 